Meheretu Yonas, Sluydts, V., Kiros Welegerima, Bauer, H., Mekonen Teferi, Gidey Yirga, Mulungu, L., Mitiku Haile, Nyssen, J., Deckers, J., Makundi, R., Leirs, H., 2014. Rodent abundance, stone bund density and its effects on crop damage in the Tigray highlands, Ethiopia. Crop Protection, 55: 61-67.

\title{
Rodent abundance, stone bund density and its effects on crop damage in the Tigray highlands, Ethiopia
}

Yonas Meheretu ${ }^{\text {a.b }}$, Vincent Sluydts ${ }^{\mathrm{c}}$, Kiros Welegerima $^{\mathrm{a}}$, Hans Bauer ${ }^{\mathrm{d}}$, Mekonen Teferi $^{\mathrm{a}}$, Gidey Yirga ${ }^{\mathrm{a}}$, Loth Mulungu ${ }^{\mathrm{e}}$, Mitiku Haile $^{\mathrm{f}}$, Jan Nyssen $^{\mathrm{g}}$, Jozef Deckers ${ }^{\mathrm{h}}$, Rhodes Makundi ${ }^{\mathrm{e}}$, Herwig Leirs ${ }^{\mathrm{b}}$

${ }^{a}$ Mekelle University, Department of Biology, P.o.box 3102, Mekelle, Ethiopia.

${ }^{b}$ University of Antwerp, Evolutionary Ecology Group, Groenenborgerlaan 171, Antwerp 2020, Belgium.

c , Nationalestraat 155, 2000 Antwerp, Belgium.

${ }^{\mathrm{d}}$ Department of Earth and Environmental Sciences, Catholic University of Leuven, Celestijnenlaan 200E, B-3001 Heverlee, Belgium.

${ }^{\mathrm{e}}$ Sokoine University of Agriculture, Pest Management Center, P.o.box 3110, Morogoro, Tanzania.

${ }^{\mathrm{f}}$ Department of Land Resources Management and Environmental Protection, Mekelle University, P.0.box 231, Mekelle, Ethiopia.

${ }^{g}$ Department of Geography, Ghent University, B-9000 Gent, Belgium.

${ }^{\mathrm{h}}$ Division of Soil and Water Management, K.U. Leuven, Celestijnenlaan 200E, 3001 Heverlee, Belgium. 


\section{Institution where the work is carried out:}

University of Antwerp

Department of Biology

Evolutionary Ecology Group

Groenenborgerlaan 171

Antwerp 2020, Belgium.

\section{Corresponding author:}

Yonas Meheretu

Present address: Department of Biology, Mekelle University, P.o.box 3102, Mekelle, Ethiopia. E-mail - meheretu@yahoo.com, Tel. +251914721856. 


\begin{abstract}
In areas of subsistence agriculture, a variety of soil conservation methods have been implemented in the last few decades to improve crop yields, however these can have unintended consequences such as providing habitat for rodent pests. We studied rodent population dynamics and estimated crop damage in high and low stone bund density fields for four cropping seasons in Tigray highlands, northern Ethiopia. Stone bunds are physical structures for soil and water conservation, and potentially habitat for rodents. We used a general model to relate the proportion of crop damage to rodent abundance, stone bund density and crop stages. Generally, rodent abundance remained relatively low during the study period, except during the fourth quarter of the 2010 cropping season. We found a positive correlation between rodent abundance and crop damage, and significant variation in rodent abundance and crop damage between high and low stone bund density fields. Furthermore, crop damage also varied significantly between crop stages. We concluded that Mastomys awashensis (Lavrenchenko, Likhnova and Baskevich 1998) and Arvicanthis dembeensis (Ruppel 1842) were the two most important crop pests in Tigray highlands causing significant damage. Fields with high stone bund density $(\sim 10 \mathrm{~m}$ average distance apart) harbor more rodents and endure a significantly higher proportion of crop damage compared to fields with lower stone bund density ( $15 \mathrm{~m}$ average distance
\end{abstract}


apart). The fact that rodent abundances peaked during the reproductive stage of the crop and around harvest implies the need for management intervention before these crop stages are attained.

Key words: rodent dynamics; crop damage; stone bund; pest control; Ethiopian highlands.

\section{Introduction}

Approximately 50\% of the Tigray province, Northern Ethiopia, is classified as highland (>2500m a.s.l), characterized by rugged geomorphic features and steep slopes with narrow intermountain valleys (Vancampenhout et al. 2006). The population of the highland has grown quickly in the last few decades, at a growth rate of $2.5 \%$ per year with an average family size of five persons per household (CSA, 2008), but the livelihood of rural families depends on small scale subsistence agriculture (Pender and Gebremedhin, 2007). Crop production is predominantly rainfed with little irrigation. The most important constraints to crop production in the highlands are soil erosion and fertility loss, erratic rainfall, low cereal yield and pre- and post-harvest crop losses to pests (Woldehanna, 2002; Lemenih et al. 2005; Vancampenhou et al. 2006; Pender and Gebremedhin, 2007).

In Ethiopia, estimates indicate 15-40\% pre-harvest loss due to pests in field crops (e.g. cereals, pulses and oil seed), 13-29\% loss in horticultural crops (e.g. root crops), 9$48 \%$ loss in coffee and 21-60\% loss in cotton annually (Amera and Abate, 2008). Other estimates show that pre- and post-harvest losses to insects, diseases, weeds and vertebrate pests add up to 30-40\% (Abesha, 2006). As in most of the Sub-Saharan African countries, insect pests are a major agricultural concern in Ethiopia. Migratory insects, such as the 
African armyworm (Spodoptera exempta) and regular pests, such as the Russian wheat aphid (Diuraphis noxia), occur frequently and result in significant yield losses (Abate, 2006; Belay and Stauffer, 2007). The most common vertebrate pests are the red-billed quelea (Quelea quelea) and several species of rodents.

In Ethiopia, approximately 84 species of rodents have been recorded; a dozen of which are considered agricultural pests (Bekele et al. 2003). The most common pest rodents with widespread distribution in the country belong to two genera: Mastomys (Thomas) and Arvicanthis (Lesson) (Bekele et al. 2003). Farmers in central (Makundi et al. 2003) and Northern Ethiopia (Meheretu et al. 2010) have ranked rodents as the number one pre- and post-harvest crop pests. Bekele et al. (2003), for example, reported 26.4\% yield loss of maize crops in the fields due to rodent attacks in central Ethiopia. In northern Ethiopia, surveyed farmers estimated 9-44\% pre-harvest yield loss in annual production to cereal crops due to rodent attacks (Meheretu et al. 2010).

Farmers and experts in the Tigray highlands have also become increasingly concerned that some of the local methods used to combat soil erosion and fertility loss are in fact promoting rodent pests (Gebremichael and Herweg, 2000; Beshah, 2003; Nyssen et al. 2001, 2007; Meheretu et al. 2010). Massive soil and water conservation programs focusing on crop fields have been initiated in Tigray in recent decades, and one of these methods, the building of stone bunds, is of particular concern. Stone bunds are rock walls built from large basaltic or limestone rock fragments, reinforced by gravel and soil to reduce holes/gaps between the stones (Nyssen et al. 2001). They are built following the contours of the topography, with an average height of approximately $1 \mathrm{~m}$. In general, the morphology (height, width and length) of the stone bunds in crop fields is influenced by 
factors such as type of topography (e.g. slope, gully), size of neighboring farms, and amount of rock fragments in the filed (Nyssen et al. 2001). The stone bunds are also used to demarcate individual crop fields. The stone bunds therefore potentially provide extensive and continuous suitable refugia for rodents within cropping areas, and there are concerns that high stone bund densities in crop fields are associated with high rodent abundance, leading ultimately to more crop damage (Gebremichael and Herweg, 2000; Beshah, 2003; Nyssen et al. 2001, 2007; Meheretu et al. 2010).

Yet despite widespread reports of significant crop damage by rodents in Tigray (and in Ethiopia at large), little is known about the ecology and population dynamics of the rodent species. Moreover, empirical estimates of crop damage and yield loss due to rodents are scarce. Nevertheless, knowledge of the relationship between pest population dynamics, farming techniques and crop damage and the factors contributing to these relationships are essential to predict future rodent population dynamics and subsequent crop damage, and to therefore devise a plan for sustainable management (Leirs, 2003; Singleton et al. 2005; Witmer, 2007).

The objectives of this study were therefore to investigate the temporal dynamics of rodent populations in rainfed crop fields in the Tigray highlands, and to relate this to stone bund density and the level of pre-harvest damage and loss to mixed barley and wheat crops. Furthermore, we report the effects of changes in crop developmental stages on rodent population dynamics. We predicted (i) crop damage to be positively associated with rodent abundance, (ii) rodent abundance to be positively associated with stone bund density and (iii) crop developmental stage to have non-linear effect on rodent abundance. 


\section{Methods}

\subsection{Study area}

The study was conducted in four rainfed crop fields in the May Zeg-Zeg catchment ( 200 ha) near the town of Hagere Selam $\left(13^{\circ} 40^{\prime} \mathrm{N}, 39^{\circ} 10^{\prime} \mathrm{E}\right)$, Northern Ethiopia, from April 2007 to February 2011 (Fig. 1). The altitude of the study area is about $2600 \mathrm{~m}$ a.s.1. and the morphology of the Hagere Selam area is typical for the Tigray highlands (see Nyssen et al. 2010 for a detailed description). The area has an annual average rainfall of $762 \mathrm{~mm}$ (as reported for 1970-2005 by Nyssen et al. 2010) and the main rainy season runs from June to September. Crop production depends on this rain as little irrigation is practiced and cropped fields are the dominant land use (about 65\%) in the study area. The typical land use is crop fields in the flat areas and lesser slopes and rangeland and exclosures (guarded areas where grazing and farming are not allowed) on the steep slopes. The remaining native vegetation is largely dominated by Acacia etbaica and Euclea schimperi.

The experimental grids were situated on a basaltic Vertic Cambisol soil, where stone bunds were built in the last two decades to prevent soil erosion (Nyssen et al. 2008). The main crops grown were wheat (Triticum sp.), barley (Hordeum vulgare), a mixture of wheat and barley, and teff (Eragrostis tef); these are staple crops in the highlands. Cereal grains, such as wheat and barely, are sown after the early rains in June; crops reach milky stage in August, mature in October and are harvested in November. Other commonly cultivated crops include grass pea (Lathyrus sativus), horse bean (Vicia faba) and lentil (Lens culinaris). Rainfall data for Hagere Selam was obtained from the 
National Meteorological Agency; the Hagere Selam weather station is approximately 2 $\mathrm{km}$ from the study area.

\section{Fig. 1}

\subsection{Grid setup}

Four permanent square grids $(60 \times 60 \mathrm{~m})$ were set in four mixed barley and wheat crop fields, situated more than 200m apart. Two of the grids represented fields with low stone bund density (LSBD) and the other two represented fields with high stone bund density (HSBD). We defined LSBD grids as those with stone bunds spaced $\sim 15 \mathrm{~m}$ average distance apart while HSBD grids had stone bunds spaced 10m apart. All farming practices were conducted according to the conventional farming system followed by the farmers in the area. Crop variety and agronomic practices were kept the same (synchronized) in each grid each year.

\subsection{Rodent trapping}

A Capture-Mark-Release (CMR) technique was used to study the population dynamics of the rodent species. Each grid consisted of seven parallel lines, $10 \mathrm{~m}$ apart, with trapping stations also $10 \mathrm{~m}$ apart (i.e. a total of 49 trapping stations per grid). Trapping was conducted with Sherman LFA live traps $(7.5$ x 9.0 x $23.0 \mathrm{~cm}$, HB Sherman Trap Inc, Tallahassee, USA) baited with peanut butter. In each grid, trapping was conducted simultaneously for three consecutive nights every fourth week. Traps were checked early in the morning and captures were marked by toe clipping and released at the point of capture (following the ethical policies and guidelines approved by the committee for Animal Care and Use (Mekelle University). 


\subsection{Damage estimation}

At milky and maturation stages (about a week before harvest), we surveyed the grids in order to visualize the distribution of rodent damage. Sections of the grids with relatively similar damage intensity were grouped in strata as low, medium or heavy damage based on the ratings of $0-25,26-50$, and $>50 \%$ damage, respectively, and the proportion of each rating within each stratum was determined by averaging the visual estimates of two independent assessors. Then, within each stratum, the number of cut and uncut stems was counted in a quadrat of $50 \times 50 \mathrm{~cm}$. Fifteen quadrats were sampled per grid, and the proportion of quadrats sampled per damage stratum mirrored the proportion of the grid within each stratum. Stratified quadrat sampling technique was preferred over other commonly used sampling techniques, such as systematic row sampling technique. In the Tigray highlands, crop seeding is conducted by broadcasting (i.e. not in rows) and stratified sampling method is recommended where rodent damage does not appear to be random (Aplin et al. 2003; Mulungu et al. 2007).

Damage by rodents was distinguished by the characteristic oblique cut through the stems near the base. The proportion of stems cut (proportion of damage) was calculated from ((the number of stems cut / the total number of stems (cut and uncut)) X 100). The mean proportional damage was calculated for the whole grid based on the proportion of damage for each stratum. For crop loss estimation, 15 panicles were randomly cut from each quadrat at maturation stages. Weights of seeds per panicle were estimated and moisture content was measured for a sample of grains from each quadrat. 


\subsection{Statistics}

Rodent population abundance was estimated from the 3-day CMR trapping sessions using the $\mathrm{m}(h)$ estimator of the Program CAPTURE (White et al. 1982). This estimator assumes sampling from a closed population during a trapping session and allows for individual variations in probability of capture (heterogeneity model). This model is commonly used to estimate abundance in rodent populations and appears quite robust (Parmenter et al. 2003).

A generalized linear mixed model was fitted to the data to relate the observed variation in crop damage (the response variable, proportion of damage measured) to rodent abundance $(\mathrm{m}(h)$, continuous), different crop stages (2 levels: milky and maturation), stone bund density (2 levels: LSBD and HSBD), and year. A logit link function was used to properly model the proportion of damage observed and a binomial distribution was assumed to assess statistical inference. Interannual variation was taken into account by considering factor year as a random effect in the statistical model. Model selection was based on AIC and likelihood ratio test (LRT) (LRT was used to verify whether the random effect year should be incorporated into the model, while AIC was used to make a selection of the different variables to model) and we used a top-down protocol as described in Zuur et al. (2009). We used the statistical software R-2.13.0 (R Development Core Team, 2010) and the statistical package lme4 (Bates and Maechler, 2010). 


\section{Results}

\subsection{Species composition, rodent abundance and density of stone bunds}

A total of 1,365 small mammals belonging to at least four species of rodents and one insectivore (Soricidae) were captured in a total of 27,636 trap nights (Table 1). About $64 \%$ of the small mammals were captured in the HSBD grids, which was significantly higher than in the LSBD grids $\left(X^{2}=149.102\right.$, d.f $\left.=4, p<0.0001\right)$. The multimammate rat Mastomys awashensis and the grass rat Arvicantis dembeensis were the two dominant rodent species, accounting for $87.1 \%$ of the captures. While the monthly abundance of $M$. awashensis was higher than that of A. dembeensis in LSBD grids throughout the trapping period (Fig. 2a), the abundance of the two species varied little in HSBD grids, except from November 2010 to February 2011 when there was an outbreak of both species, and especially of A. dembeensis (Fig. 2b). However, only the proportion of A. dembeensis was significantly higher in the HSBD grids than LSBD grids $\left(X^{2}=72.5767, \mathrm{df}=1, p<\right.$ 0.0001). Trap success ((total number of animals trapped / total number of trap night) X 100) was $6.4 \%$ in HSBD grids and $3.5 \%$ in LSBD grids. The other rodent species trapped were the spiny mouse Acomys spp. and Mus (Nannomys) spp.; Mus (Nannomys) were trapped only between July 2010 and February 2011. A small number of African Giant Shrews Crocidura olivieri (3.3\%) were also captured, but were not considered in the estimation of abundance.

\section{Table 1}

\section{Fig. 2}




\subsection{Seasonality, crop stage and rodent abundance}

Generally, rodent abundance varied seasonally during the study period (Fig. 2a \& b). The seasonal changes in the abundance showed two sets of peaks each year; the highest peaks occurring early in the dry season (October to January) - hereafter called "early dry season peak", and the second peaks occurring in the wet season (July to August) - hereafter called "wet season peak". A drop in abundance was observed immediately after the wet season peaks across the study period (October 2007, 2008, and 2009 and September 2010), followed by a resurgence of abundance in the following months, resulting in the early dry season peaks. Note that the cropping stages are related to the wet and early dry season peaks correspond with milky stage and harvest respectively (Fig. 3).

\subsection{Rodent abundance, crop damage and yield loss}

In the HSBD grids, the mean crop damage was $7.1 \%$ ((range: $4.6 \%$ (2009) $10.7 \%$ (2007)) and 5.0\% ((range: $3.1 \%(2009)-8.3 \%(2010)$ ) at the milky and maturation crop stages, respectively. In LSBD grids, the mean damage was $3.8 \%$ ((range: $2.3(2009)-5.6 \%(2007))$ and $4.1 \%(($ range: $2.4 \%(2009)-7.7 \%(2010))$ at the milky and maturation crop stages, respectively.

The generalized mixed model showed that rodent abundance, stone bund density and crop stage all contributed to explaining the observed variation in crop damage (Table 2). We fitted a final model including rodent abundance, stone bund density, crop stage and an interaction between crop stage and stone bund density (model 4). The likelihood ratio test comparing this model versus one without the interaction term (model 5) was highly significant $\left(X^{2}=74.7, \mathrm{df}=1, p<0.0001\right)$. Year was incorporated as a random effect term to take into account that we measured crop damage and rodent abundance on 
the same grids over a four year period. The intraclass correlation was estimated as 0.06 indicating that the design effect was low.

\section{Table 2}

Since our model was build on the logit scale using a binomial distribution to model the response variable (damage versus no-damage), we summarized the model outcome using a plot of the already backtransformed coefficients (Fig. 3). The graph clearly shows a positive correlation between rodent abundance and damage. We found higher damage estimates in the HSBD grids, both at the milky and maturation stages. This relationship was stronger during milky stage, however, where the difference in damage at a density of 40 rodents per $\mathrm{h}^{-1}$ reached $50 \%$ between LSBD and HSBD grids.

\subsection{Estimated loss}

On average, our estimate for number of stems per quadrat was 125 and the seed weight per panicle was $0.9 \mathrm{~g}$ (at $12.2 \%$ moisture content on average, about a week before harvest). The estimated amount of crop loss in HSBD grids, from the average damage at maturation stage (5.0\%), was $225 \mathrm{~kg} \mathrm{ha}^{-1}$ (range: 140 - $373 \mathrm{~kg} \mathrm{ha}^{-1}$ ). The estimated loss in LSBD grids, from the average damage at maturation stage (4.1\%), was $180 \mathrm{~kg} \mathrm{ha}^{-1}$ (range: $108-347 \mathrm{~kg} \mathrm{ha}^{-1}$ ). Taking in to account the price of wheat and currency exchange rate for $2010\left(\sim 750\right.$ Birr q $^{-1}$ and 1 US $\$=14$ Birr, respectively $)$, the average loss in HSBD grids was equivalent to 1,688 Birr (121 US\$) (range: 1,046 (75) - 2,801 Birr (200 US\$)). The average loss in LSBD grids was equivalent to 1,350 Birr (96 US\$) (range: 810 (58) 2599 Birr (187 US\$)). 


\section{Fig. 3}

\section{Discussion}

\subsection{Species composition}

The multimammate rat Mastomys awashensis and the grass rat Arvicanthis dembeensis were the two dominant rodent species in rainfed crop fields in Tigray highlands. Nyssen et al. (2007) also reported M. awashensis and another Arvicantis species, A. niloticus, as the two dominant species in Tigray highlands (accounting for $91 \%$ of captures). In irrigated cereal and vegetable fields in other parts of Tigray, about $130 \mathrm{~km}$ North West of Hagere Selam and at a slightly lower altitude ( 2000m), M. erythroleucus and A. dembeensis were reported as the dominant species (accounting for 93\% of captures) (Gebresilassie et al. 2004). Bekele and Leirs (1997) have also reported the latter two species, accounted for $87 \%$ of captures, in maize fields in central Ethiopia.

\subsection{Rodent abundance and stone bunds}

The overall proportion of the small mammals captured was significantly higher in HSBD grids than in LSBD grids. Several reports showed higher rodent abundances correlated with presence of better vegetation and structural cover (Massawe et al. 2006; Jacob, 2003, 2008; Birkedal et al. 2009). However, at the species level only the abundance of Arvicanthis dembeensis varied significantly between the two stone bund densities, with

more A. dembeensis in HSBD grids than in LSBD grids. We suggest that this is because A. dembeensis is a heavier and diurnal species (Challet et al. 2002) which seeks relatively more cover against potential predators. Our findings are in line with Nyssen et al. (2007), who also found such differences in species abundance with variation in stone bund density using data collected from one cropping season (between June to November). 


\subsection{Rodent abundance and crop phonological stage}

Rodent abundance was more pronounced during the reproductive stages of the crop (milky and fruiting stages) and around harvest. It appeared that as the crops developed towards the reproductive stages, so did the availability and quality of food and cover (crop height) which may have been conducive for rodent population growth. Similar increases in rodent abundance in the course of crop development and increasing vegetation cover have been reported by Brown et al. (2007) and Jacob (2008). The pattern we observed appears to occur with much regularity following crop development, making decision making for application of control measures somewhat less challenging. This finding is therefore a very useful input for rodent pest management in the highlands of Ethiopia.

Surprisingly, we were unable to explain why the rodent abundance dropped at maturation stage of the crop. Crop maturation usually coincides with the onset of the dry season, at a time when new individuals might be recruited into the population (Leirs, 1992; Makundi et al. 2009; Masssawe et al. 2011). Asynchronous planting among the farmers resulted in varied crop stages in the already mosaic fields of the Tigray highlands. This might encourage rodents to move between neighboring fields with different crop stages in search of better quality food and could have lowered the population in the study grids. Predation by avian and mammalian predators may also have contributed to lower rodent populations at the beginning of the dry season, although their impact in the current study is unknown. Predator impacts on rodent populations can be direct or indirect. In the former, predators influence population dynamics by physically removing individuals, whereas in the latter case the presence of predators 
induces behavioral or physiological responses on the prey due to perceived risk, reducing the probability of being captured (Mohr et al., 2003; Vibe-Petersen et al., 2006).

\subsection{Crop damage and loss}

The generalized mixed model result showed correlation between the proportion of crop damage and abundance of rodents. We found a significantly higher proportion of damage in HSBD grids, particularly at milky stage, than in LSBD grids. This was consistent with the proportion of rodents captured, which was significantly higher in HSBD grids than LSBD grids. Importantly, the abundance of rodents in the HSBD grids was not only higher, but also consisted of relatively more Arvicanthis dembeensis. A. dembeensis is larger and heavier than M. awashensis, and it also consumes more biomass than M. awashensis; we propose that the combination of these factors was the cause of the greater crop damage in the HSBD. The presence of stone bunds relatively close to each other might have lowered the perceived risk of predation and generated better foraging opportunities for this species. Our result was consistent with that of the farmers' survey in Hagere Selam in that the same crop stage experienced the most critical damage (Meheretu et al. 2010). Gebresilassie et al. (2004) also reported intense rodent attacks during the fruiting stage in irrigated cereal fields in Tigray. The presence of higher proportion of grain protein, fat and several of the B-vitamins in the germ (seed bud) at milky stage have been argued to supply the dietary requirement of the rodents (Leirs et al. 1990; 1993; Mutze, 2007; Kumar et al. 2011).

Considering an estimate of $0.5 \mathrm{~kg}$ average daily per capita grain consumption per person in Ethiopia (country wide annual per capita grain consumption was estimated as 
$176 \mathrm{~kg}$ (Robinson et al., 2006)), the average loss in HSBD fields could have supported a family of 5 heads for about 3 months (range: $1.9-5$ months) and the average loss in LSBD fields could have supported a family of the same size for about 2.4 months (range: $1.4-4.6$ months). Hence, the average loss caused by HSBD, about $25 \%$ more than the loss suffered in LSBD, roughly equates to two weeks of extra food. For somebody who has just enough to eat, two weeks extra food is important; for somebody who has enough to eat but no money, for instance, to buy textbooks to his children, the equivalent of two weeks eating is also equality important, but the relative effect is less. Note that these estimates do not include the losses suffered during the rest of the crop stages.

In conclusion, in terms of pest management, increasing the distance between stone bunds in crop fields may reduce rodent numbers and ultimately crop damage (at least of the latter species). The fact that rodent abundances peaked during the reproductive stages of the crop and around harvest entail serious pest management intervention before these crop stages are attained.

\section{Acknowledgments}

We are grateful to the Flemish Interuniversity Council (VLIR), Belgium, for funding the Ph.D of Y.M.. We thank N. Hughes for helpful comments and native English proofing, Departments of Biology in Mekelle (Ethiopia) and Antwerp (Belgium) Universities for provision of laboratory facilities, and Mekelle University-Institutional University Cooperation (MU-IUC) project staff for facilitating the fieldwork.

\section{References}


Abate, T., 2006. IPM in Ethiopia: The Current Status. In Facilitating the Implementation and Adoption of Integrated Pest Management (IPM) in Ethiopia: 3-15. Bekele, E., Azerefegne, F. and Abate, T. (Eds.). Oslo: Drylands Coordination Group (DCG).

Abesha, D., 2006. Pest Management Practices in Smallholder Agriculture: The Agricultural Extension Perspective. In Facilitating the Implementation and Adoption of Integrated Pest Management (IPM) in Ethiopia: 109-110. Bekele, E., Azerefegne, F. and Abate, T. (Eds.). Oslo: Drylands Coordination Group (DCG).

Amera, T., Abate, A., 2008. An assessment of the pesticide use, practice and hazards in Ethiopian Rift Valley. USA, Africa Stockpiles Programme (ASP).

Aplin, K.P., Brown, P.R., Jacob, J., Krebs, C.J., Singleton, G.R., 2003. Field methods for rodent studies in Asia and the Indo-Pacific. Canberra: Australian Centre for International Agricultural Research.

Bates, D., Maechler, M., 2010. Lme4: Linear mixed-effects models using S4 classes. R Package Version 0.999375-37. Available at http://lme4.r-forge.r-project.org/.

Bekele, A., Leirs, H., 1997. Population ecology of rodents of maize fields and grassland in central Ethiopia. Belg. J. Zool. 127 (Supl. I), 39-48.

Bekele, A., Leirs, H., Verhagen, R., 2003. Composition of rodents and damage estimates on maize farms at Ziway, Ethiopia. In Rats, Mice and People: Rodent Biology and Management: 262-263. Singleton, G.R., Hinds, L.A., Krebs, C.J., Spratt, D.M. (Eds.). Canberra: Australian Centre for International Agricultural Research. Belay, T., Stauffer, C., 2007. Low genetic variability among worldwide populations of Russian wheat aphid (RWA), Diuraphis noxia (Mordvilko). African Crop Science 
Conference Proceeding, Vol. 8. pp. 621-626. Egypt: El-Minia: African Crop Science Society.

Beshah, T., 2003. Understanding farmers: Explaining soil and water conservation in Konso, Wolaita and Wello, Ethiopia. PhD Thesis, Wageningen university and research center. The Netherlands.

Birkedal, M., Fischer, A., Karlsson, M., Löf, M., Madsen, P. 2009. Rodent impact on establishment of direct-seeded Fagus sylvatica, Quercus robur and Quercus petraea on forest land. Scand J Forest Res. 24, 298-307.

Brown, P.R., Huth, N.I., Banks, P.B., Singleton, G.R., 2007. Relationship between abundance of rodents and damage to agricultural crops. Agric. Ecosyst. Environ. 120, 405-415.

Central Statistics Agency (CSA), 2008. National population statistics. Addis Ababa, Ethiopia.

Challet, E., Pitrosky, B., Sicard, B., Malan, A., Pévet, P., 2002. Circadian Organization in a Diurnal Rodent, Arvicanthis ansorgei Thomas 1910: Chronotypes, Responses to Constant Lighting Conditions, and Photoperiodic Changes. J. Biol. Rhythms. 17, 5264.

Gebremichael, Y., Herweg, K., 2000. Soil and water conservation - from indigenous knowledge to participatory technology development. Center for Development and Environment, University of Berne, Switzerland. pp. 52.

Gebresilassie, W., Bekele, A., Belay, B., Balakrishnan, M., 2004. Microhabitat choice and diet of rodents in Maynugus irrigation field, northern Ethiopia. Afr. J. Ecol. 42, 315-321. 
Jacob, J., 2003. Short-term effects of farming practices on populations of common voles. Agric. Ecosyst. Environ. 95, 321-325.

Jacob, J., 2008. Response of small rodents to manipulations of vegetation height in agroecosystems. Integ. Zool. 3, 3-10.

Kumar, P., Yadava, R.K., Gollen, B., Kumar, S., Verma, R.K., Yadav, S., 2011.

Nutritional Contents and Medicinal Properties of Wheat: A Review. Life Sci. Med. Res. V. 2011: LSMR-22.

Leirs, H. 1992. Population ecology of Mastomys natalensis (Smith, 1834) multimammate rats: possible implications for rodent control in Africa. $\mathrm{PhD}$ thesis. University of Antwerp, Belgium.

Leirs, H., Stuyck, J., Verhagen, R., Verheyen, W., 1990. Seasonal variation in growth of Mastomys natalensis (Rodentia, Muridae) in Morogoro, Tanzania. Afr. J. Ecol. 28, 298-306.

Leirs, H., Verhagen, R., Verheyen, W., 1993. Productivity of different generations in a population of Mastomys natalensis rats in Tanzania. Oikos, 68, 53-60.

Leirs, H., 2003. Management of rodents in crops: the Pied Piper and his orchestra. In: Rats, Mice and People: Rodent Biology and Management: pp. 183-190. Singleton, G.R., Hinds, L.A., Krebs, C.J., Spratt, D.M. (Eds.). Camberra: Australian Centre for International Agricultural Research.

Lemenih, M., Karltun, E., Olsson, M., 2005. Assessing soil chemical and physical property responses to deforestation and subsequent cultivation in smallholders farming system in Ethiopia. Agric. Ecosyst. Environ. 105, 373-386. 
Makundi R.H., Bekele, A., Leirs, H., Massawe, A.W., Rwamugira, W., Mulungu, L.S., 2003. Farmer's Perception of rodents as crop pests: Knowledge, attitude and practice in rodent pest management in Tanzania and Ethiopia. Belg. J. Zool. 135 (Supl.), 153157.

Makundi, R.H., Massawe, A.W., Mulungu, L.S., Katakweba, A. 2009. Diversity and population dynamics of rodents in farm-fallow mosaic fields in Central Tanzania. Afr. J. Ecol. 48: 313-320.

Massawe, A.W., Rwamugira, W.P., Leirs, H., Makundi, R.H., Mulungu, L.S. 2006. Do farming practices influence population dynamics of rodents? A case study of multimammate filed rats, Mastomys natalensis in Tanzania. Afr. J. Ecol. 45, 293-301.

Massawe, A.W, Mulungu, L.S, Makundi, R.H, Dlamini, N., Eiseb. S., Kirsten, F., Mahlaba, T., Malebane, P., Maltitz, E.V., Monadjem. A., Taylor, P., Tutjavi, V., Belmain, S.R. 2011. Spatial and temporal population dynamics of rodents in three geographically different regions in Africa: Implication for ecologically- based rodent management. Afr. Zool. 46(2): 393-405.

Meheretu, Y., Kiros, W., Deckers, S., Raes, D., Makundi, R., Leirs, H., 2010. Farmers’ perspectives of rodent damage and management from the highlands of Tigray, Northern Ethiopia. Crop Prot. 29(6), 532-539.

Mohr, K., Vibe-Petersen, S., Jeppesen, L.L., Bildsøe, M., Leirs, H., 2003. Foraging of multimammate mice (Mastomys natalensis) under different predation pressure: cover, patch dependent decisions and density-dependent GUDs. Oikos, 100, 459-468. 
Mulungu, L.S., Makundi, R.H., Massawe, A.W., Leirs, H., 2007. Relationship between sampling intensity and precision for estimating damage to maize caused by rodents. Integ. Zool. 2, 131-135.

Mutze, G., 2007. Does high growth rate of juvenile house mice with prolonged access to ripening grain and free water drive population outbreak. New Zeal. J. Zool. 34, 195202.

Nyssen, J., Poesen, J., Desta, G., Vancampenhout, K., D’aes, M., Gebremedhin, Y., Govers, G., Leirs, H., Moeyersons, J., Naudts, J., Nigussie, H., Mitiku, H., Deckers, J., 2007. Interdisciplinary on-site evaluation of stone bunds to control soil erosion on cropland in Northern Ethiopia. Soil. Tillage. Res. 94, 151-163.

Nyssen, J., Naudts, J., De geyndt, K., Haile, M., Poesen, J., Moeyersons, J., Deckers, J., 2008. Soils and land use in the Tigray Highlands (Northern Ethiopia). Land Degrad. Devt. 19, 257-274.

Nyssen, J., Clymans, W., Descheemaeker, K., Poesen, J., Vandecasteele, I., Vanmaercke, M., Zenebe, A., Van Camp, M., Haile, M., Haregeweyn, N., Moeyersons, J., Martens, K., Gebreyohannes, T., Deckers, J., Walraevens, C., 2010. Impact of soil and water conservation measures on catchment hydrological response- a case in north Ethiopia. J. Hydrol. Process. 24, 1880-1895.

Nyssen, J., Haile, M., Poesen J., Deckers J., Moeyersons J., 2001. Removal of rock fragments and its effect on soil loss and crop yield, Tigray, Ethiopia. Soil Use Manage. 17, 179-187.

Parmenter, R.R., Yates, T.L., Anderson, D.R., Burnham, K.P., Dunnum, J.L., Franklin, A.B., Friggens, M.T., Lubow, B.C., Miller, M., Olson, G.S., Parmenter, C.A., Pollard, 
J., Rexstad, E., Shenk, T.M., Stanley, T.R., White, G.C., 2003. Small-mammal density estimation: a field comparison of grid-based vs. web-based density estimators. Ecol. Monogr. 73(1), 1-26.

Pender, J., Gebremedhin, B., 2007. Determinants of agricultural and land management practices and impacts on crop production and household income in the highlands of Tigray, Ethiopia. J. Afr. Econ. 17, 395-450.

R Development Core Team, 2010. R: A Language and Environment for Statistical Computing. Vienna, Austria: R Foundation for Statistical Computing. ISBN 3900051-07-0.

Robinson W.I., Lieberg A.T., Trebbi, L., 2006. Crop and food supply assessment mission to Ethiopia. Rome: Food and Agriculture Organization of the United Nations and World Food Programme.

Singleton, G.R., Sudarmaji, Jacob, J., Krebs, C.J., 2005. Integrated management to reduce rodent damage to lowland rice crops in Indonesia. Agric. Ecosyst. Environ. $107,75-82$.

Vancampenhout, K. Nyssen, J., Gebremichael, D., Deckers, J., Poesen, J., Haile, M., Moeyersons, J. 2006. Stone bunds for soil conservation in the northern Ethiopian highlands: Impacts on soil fertility \& crop yield. Soil Tillage Res. 90, 1-15.

Vibe-Petersen, S., Leirs, H., De Bruyn, L., 2006. Effect of predation and dispersal on Mastomys natalensis population dynamics in Tanzania maize fields. J. Anim. Ecol, 75, 213-220. 
White, G.C., Anderson, D.R., Burnham, K.P., Otis, D.L., 1982. Capture-Recapture and Removal Methods for Sampling Closed Populations. USA, Los Alamos National Laboratory.

Witmer, G., 2007. The ecology of vertebrate pests and integrated pest management (IPM). In Perspectives in ecological theory and Integrated Pest Management: 393410. Kogan, M. and Jepson, P. (eds.). Cambridge, Cambridge University Press.

Woldehanna, T., 2002. Rural farm/non-farm income linkages in northern Ethiopia. In Promoting farm/non-farm linkages for rural development-case studies from Africa and Latin America. Davis, B., Reardon, T., Stamoulis, K.G., Paul, W.P. (Eds.), Rome: Food and Agriculture Organization of the United Nations.

Zuur, A.F., Ieno, E.N., Walker, N.J., Saveliev, A.A., Smith, G.M., 2009. Mixed effects models and extensions in ecology with R. New York: Springer-Verlag. 


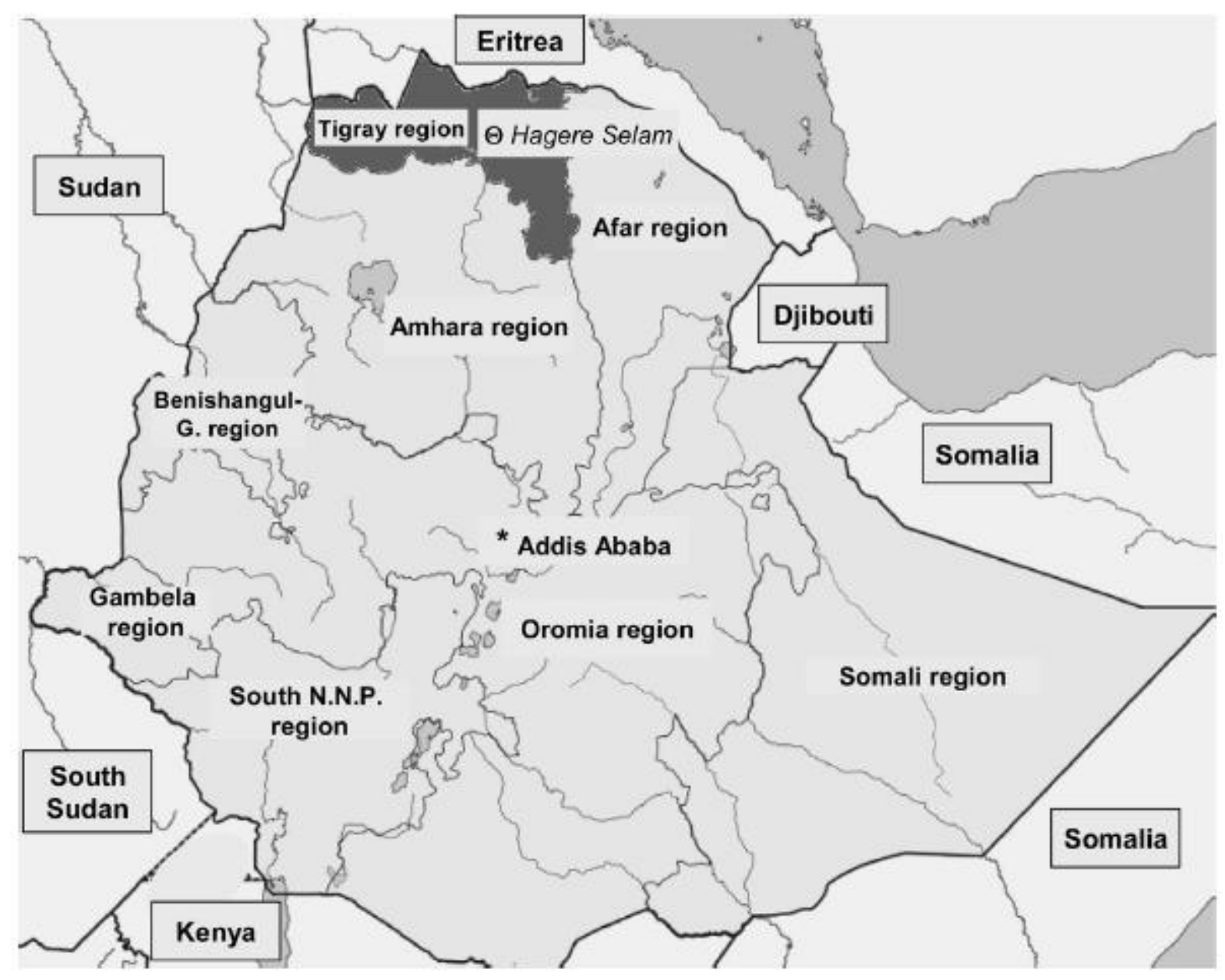

Figure 1 The approximate position of the city of Hagere Selam $(\Theta)$, in Dogu'a Temben district, Tigray province (shaded), Northern Ethiopia. 

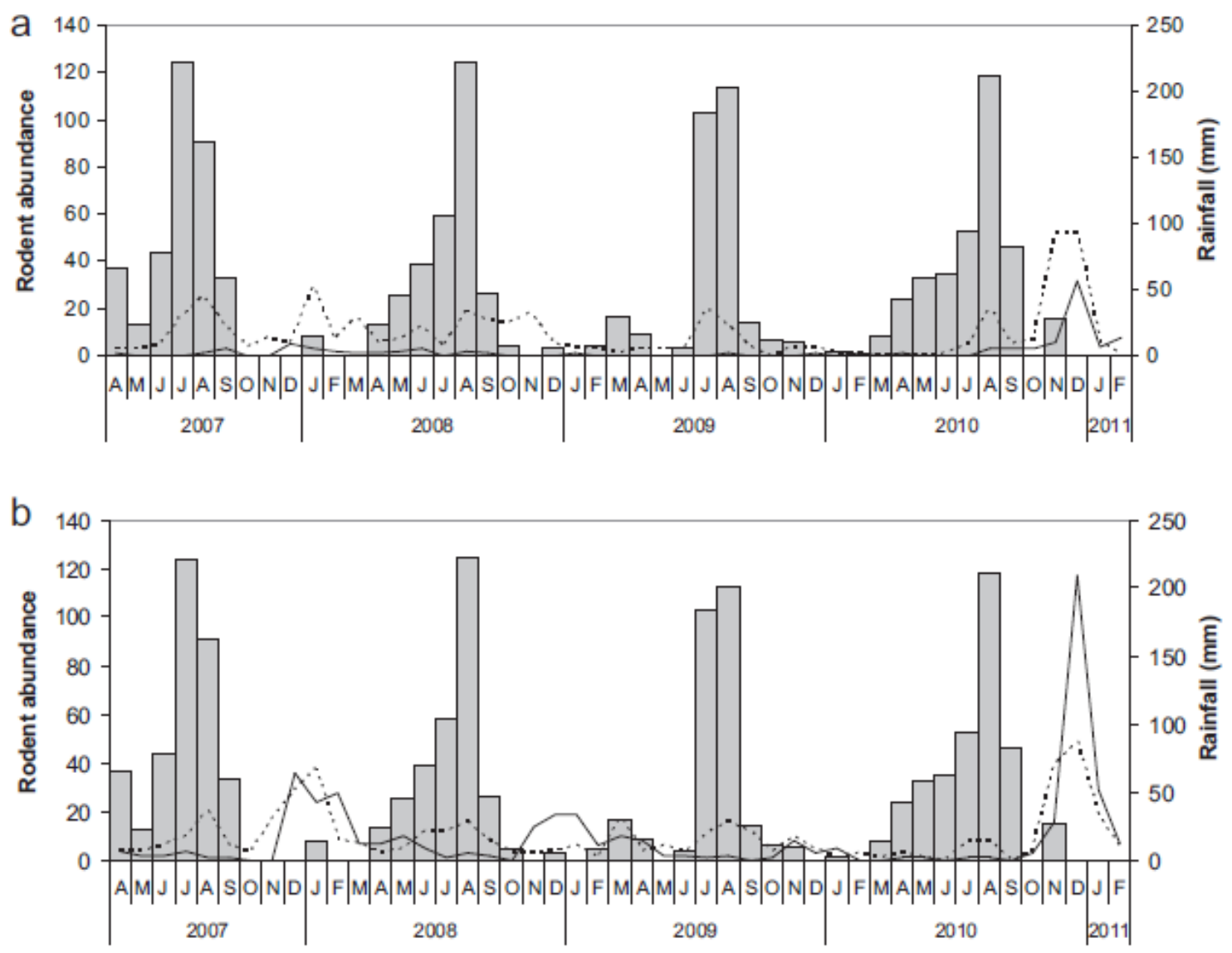

Figure 2 Monthly estimates of abundance of $M$. awashensis (dotted lines) and $A$.

dembeensis (solid lines) in LSBD (a) and HSBD (b) grids. The bars indicate monthly mean rainfall. 


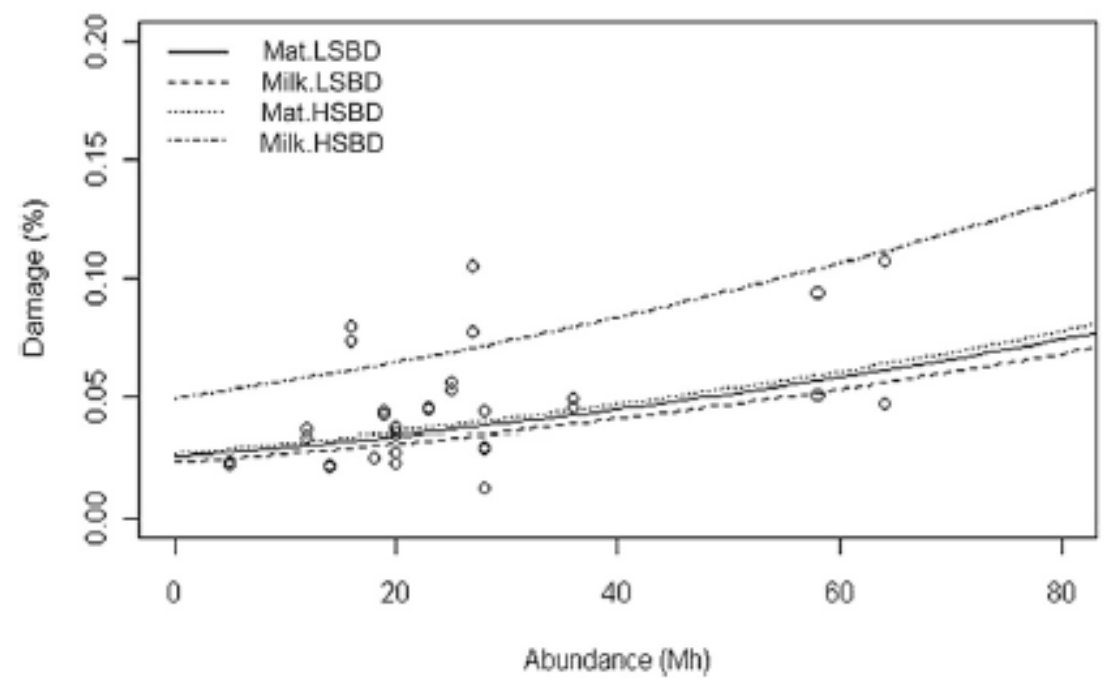

Figure 3 Relationship between rodent abundance and crop damage (\%) in a mixed wheat and barely crop at milky (Milk.) and maturation (Mat.) stages in HSBD and LSBD grids.

Table 1. Composition (number and percentage) of small mammal species trapped from LSBD and HSBD grids in rainfed crop fields around Hagere Selam, Northern Ethiopia, from April 2007 to February 2011.

\begin{tabular}{|c|c|c|c|c|c|c|}
\hline \multirow[t]{2}{*}{ Species } & \multicolumn{2}{|c|}{ LSBD grids } & \multicolumn{2}{|c|}{ HSBD grids } & \multicolumn{2}{|c|}{ Overall } \\
\hline & Count & $\%$ & Count & $\%$ & Total & $\%$ \\
\hline Mastomys awashensis & 372 & 76.4 & 390 & 44.4 & 762 & 55.8 \\
\hline Arvicanthis dembeensis & 82 & 16.8 & 345 & 39.3 & 427 & 31.3 \\
\hline Acomys spp. & 12 & 2.5 & 92 & 10.5 & 104 & 7.6 \\
\hline Mus (Nannomys) spp. & 15 & 3.1 & 12 & 1.4 & 27 & 2 \\
\hline Crocidura olivieri & 6 & 1.2 & 39 & 4.4 & 45 & 3.3 \\
\hline Total & 487 & & 878 & & 1365 & \\
\hline
\end{tabular}


Table 2 The results of the generalized linear models fitted to relate the observed variation in crop damage (perc. total) to rodent abundance $(\mathrm{m}(h))$, different crop stages (crop stage), stone bund density (stone bund), and year.

\begin{tabular}{lllllll}
\hline Model $^{\mathrm{a}}$ & AIC & BIC & log Lik & Chisq & Chi df & $\operatorname{Pr}(>$ Chisq) \\
\hline 5 & 5290.53 & 297.85 & -140.26 & & & \\
4 & 6217.84 & 226.64 & -102.92 & 74.6821 & 1 & $<0.05$ \\
3 & 7215.49 & 225.75 & -100.75 & 4.354 & 1 & 0.04 \\
2 & 8216.96 & 228.68 & -100.48 & 0.535 & 1 & 0.50 \\
1 & 9218.51 & 231.70 & -100.25 & 0.4465 & 1 & 0.50 \\
\hline
\end{tabular}

a Models key.5: perc, total $\sim \mathrm{m}(h)+$ crop stage + stone bund $+(1 \mid$ year $) .4$ : perc. total $\sim \mathrm{m}(h)+$ crop stage + stone bund + crop stage:stone bund + (1 |year $) .3$ : perc. total $\sim \mathrm{m}(h)+$ crop stage + stone bund $+\mathrm{m}(h)$ :crop stage + crop stage:stone bund $+(1 \mid$ year $) .2$ : perc. total $\sim \mathrm{m}(h)+$ crop stage + stone bund $+\mathrm{m}(h)$ :stone bund $+\mathrm{m}(h)$ :crop stage + crop stage:stone bund $+(1 \mid$ year $) .1$ : perc. total $\sim \mathrm{m}(h) \times$ crop stage $\times$ stone bund $+(1 \mid$ year $)$. 